\title{
Analyzing Public Sector Education Facilities: A Step Further Towards Accessible Basic Education Institutions in Destitute Subregions
}

\author{
Mir Aftab Hussain Talpur ${ }^{1}$, Madzlan Napiah ${ }^{1}$, Imtiaz Ahmed Chandio ${ }^{1} \&$ Irfan Ahmed Memon ${ }^{1}$ \\ ${ }^{1}$ Department of Civil Engineering, Universiti Teknologi PETRONAS, Malaysia \\ Correspondence: Mir Aftab Hussain Talpur, Department of Civil Engineering, Universiti Teknologi PETRONAS, \\ Malaysia. Tel: 16-519-6075. E-mail: aftab_g01903@utp.edu.my
}

Received: January 22, 2014 Accepted: February 25, 2014 Online Published: March 30, 2014

doi:10.5539/ies.v7n4p110 URL: http://dx.doi.org/10.5539/ies.v7n4p110

\begin{abstract}
Rural subregions of the developing countries are suffering from many physical and socioeconomic problems, including scarcity of basic education institutions. The shortage of education institutions extended distance between rural localities and education institutions. Hence, to curb this problem, this research is aimed to deal with the basic education institution's shortage, according to available local standards and demographic features. This is an attempt to lower down the distance between the rural population and basic education institutions. Data were collected through interviews, field visits and from the concerned authorities of the study area. The basic education institution's shortage is determined up to the year 2035, which could help in formulating education policy plans. It is expected that local people's accessibility towards rural education institutions can be increased, which may put a positive impact on the declining literacy rate of a rural population.
\end{abstract}

Keywords: rural subregions, education institutions, local standards, demographic features, accessibility, literacy rate, rural population

\section{Introduction}

Education is a one of the basic human rights and a necessity for the modern developing nations (Pakistan, 1998). Education to backward societies is important as a backbone for human beings. Education is considered as a road map towards the prosperity and economic well-being of people, which can assist in fighting against socioeconomic imbalances (Psacharopoulos \& Patrinos, 2004). The socioeconomic development of backward regions is directly concerned with the availability of educational facilities (Aref, 2011; Psacharopoulos, 1994). Education undoubtedly benefits not only individuals, but also cultural empowerment and a national economy. The accessible and increased basic educational facilities curtail the problems of rural areas and ensure the development process (Lasker et al., 2001). Quality education is categorized as a tool for socioeconomic changes. Literate and skilled people are the basic and important determinants of the society, which are essential for the prosperity of humanity (Schultz, 1961). The provision of basic education, especially to backward communities is obligatory for a national economy and prolonged development. A developing country, which would not pay attention to the knowledge and skills of its people, in-fact would not be able to groom itself (Hanushek, 1995). It was found that educational facilities in deprived rural regions of the developing countries are struggling to meet the needs of rural inhabitants (Asadullah, 2009). This could be mainly because of policy failure, and excessive population growth rates. The policies in these subregions were made to trounce the problems of urban areas mostly, while the rural regions always left alone on their own, without any planning programs and financial assistance. This may happen because of other burning issues, like: poverty (Zaman \& Khilji, 2013); primary health (Guagliardo, 2004) and inflation (Khan \& Saqib, 2011); which attracted policy makers of developing countries on a priority basis. Acute rural poverty is a challenging task for developing nations with higher growth rates of population. Poverty is highly related to low education standards, low enrollment and gender discrimination (Filmer, 2000). Lower-income families in rural regions found very hard to send their children for basic education. Because children can earn easily for their respective families as child labor is increasing with the passage of time in aloof areas of developing countries (Awan et al., 2011; Groot, 2007). Another reason may be the long-distance of education facilities from the residential neighborhoods in pastoral subregions without any road connectivity and transportation facilities, which negatively affect the enrollment of the students.

Regional transportation availabilities can play a fundamental role in up-gradation of rural education and its 
dropping standard (Andersson et al., 2012). With the provision of proper road connectivity and low cost transportation services, education standard as well as enrollment can be amplified to standard levels. Unavailability of education institutions in remote areas is also a sign of agonize in developing countries. The education sector, which is responsible to provide basic education services, is not able to deliver according to the area's demographic characteristics. Whilst, the scarcity of education institutions would increase with the passage of time and mammoth distance generated between rural communities and educational institutions. This situation puts a negative impact on overall education standards, as parents won't allow their children to attend schools available far away from their homes. This study resolves this problem by computing the shortage of basic education facilities with respect to demographic features, which could curtail the distance between rural communities and education facilities. It is believed that rural households would not hesitate to send their children to school, if these are provided at their doorstep. Therefore, the aim of this research article is to determine the shortage of education institutions, according to local standards and demographic features. On one hand, this step could diminish the basic education institution's shortage and increase the accessibility standards towards rural education and on the other, basic education enrollment could also be augmented in this way, which would improve the literacy ratio of deprived communities and positively influence the future development.

\section{Material and Methods}

\subsection{Study Area}

Pakistan is a developing country with a higher growth rate of population and after India, this is the second largest populated country of South Asia (Anwar et al., 2012). Pakistan is curious about its educational accessibility and quality of basic education (Farah et al., 1996); however, it was observed that Pakistan is facing basic and higher-education problems and struggling to meet with the required educational demands of its people (Halai, 2011; Sawada \& Lokshin, 2009; Fatima \& Nasr, 2010; Memon, 2007; Parveen, 2006).

For this study, a subregion of Mirpurkhas was selected, which is positioned in southern Pakistan. Mirpurkhas subregion was developed in a year 1990 for better planning and management. Before the said year, it was a part of the deserted subregion Tharparkar. Mirpurkhas subregion lies at $24^{\circ} 46^{\prime}$ to $25^{\circ} 44^{\prime}$ north latitudes and $68^{\circ} 54^{\prime}$ to $69^{\circ} 30^{\prime}$ east latitudes (see Figure 1). The subregion's total area is about 2925 square kilometers (District Census Report, 1998). 


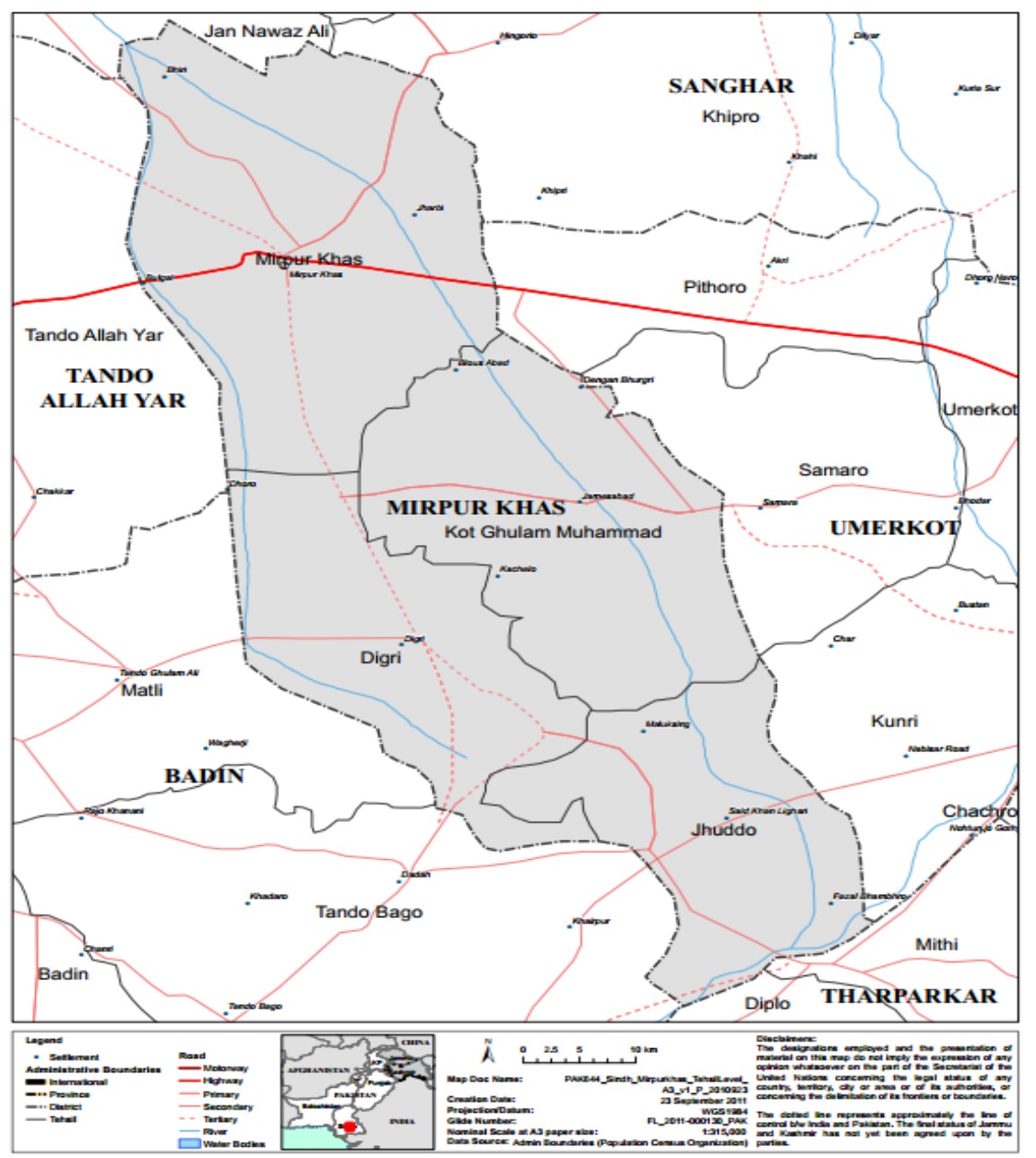

Figure 1. Mirpurkhas subregion southern Pakistan (Pakistan Humanitarian Response, 2011)

Figure 1 confirms the location of a study area without basic road network hierarchy and facilities. This situation portrays a problematic picture about the people's accessibility criteria regarding the salvage of basic facilities, including basic education. In addition, a shortage of education institutions, according to demographic features made education facilities inaccessible to the local population and lowered down the literacy ratio (see Table 1).

Table 1. Literacy ratio of Mirpurkhas subregion

\begin{tabular}{lllllll}
\hline Area & \multicolumn{3}{c}{ Year 1998 } & \multicolumn{3}{c}{ Year 2010 } \\
\hline & Both Sexes & Male & Female & Both sexes & Male & Female \\
All Areas & 35.97 & 46.00 & 25.05 & 51 & 66.9 & 33.1 \\
Rural & 23.13 & 34.21 & 10.98 & 32.54 & 48.02 & 16.98 \\
Urban & 59.80 & 68.02 & 50.92 & 69.46 & 77.82 & 61.1 \\
\hline
\end{tabular}

This should be noted that the female literacy ratio was too small in the study area as compared to the male. This was simply a result of the backward notion, as most of the parents in a rural environment and rearward societies were illiterate and did not want to send their female children for schooling.

\subsection{Methods}

In this study, data were collected through field visits, interviews, and by referring the secondary sources. For example, district census report and national policy documents (Richardson et al., 1995; Tre'panier et al., 2008; 
Stopher \& Greaves, 2007; Talpur et al., 2012). Field visits and interviews with concerned officials were conducted to know the ground realities of the study area. Meanwhile, the district census report and policy documents were also referred to obtain the demographic trends and the analytical view of social sector services, particularly education. The analytical review and comparison of demographic trends with education services are indispensable tools for the development of education policies. Policy proposals and plans intended to develop by keeping in view the demographic characteristics (Findlay \& Borgegard, 1995). To know the problems of the education sector in the study area, demographic features were evaluated and compared with the national standards. The demographic data of Mirpurkhas subregion were taken from the district census report and concerned public sector officials. The regional demographic characteristics were projected up to the year 2035 , aiming the calculation of a public sector education institution's demand. Mathematical expressions, which were used for the population projection, can be seen in Appendix I (Roberts, 1974).

\section{Results and Discussion}

Administratively, the subregion of Mirpurkhas comprises six Talukas/Tehseels, i.e. Mirpurkhas, Sindhri, Hussain Bux Mari (HBM), Digri, Jhudo and Kot Ghulam Muhammad (KGM) (District Census Report, 1998). Taluka or Tehseel is defined as a second administrative unit of local government after a District. The Taluka is a combination of different Union Councils (UCs) and UC is said to be a smallest administrative unit in the country. A city, town or village can be extended to one or more UCs according to geographic features and demographic characteristics. The existing and projected regional demographic characteristics of the Mirpurkhas subregion can be shown in Figure 2. This figure depicts that population in a year 2010 was about 1,490,632 persons and by considering the annual growth rate under three percent, it was predicted that by the year 2035 , this would be approximately $2,765,921$ persons.

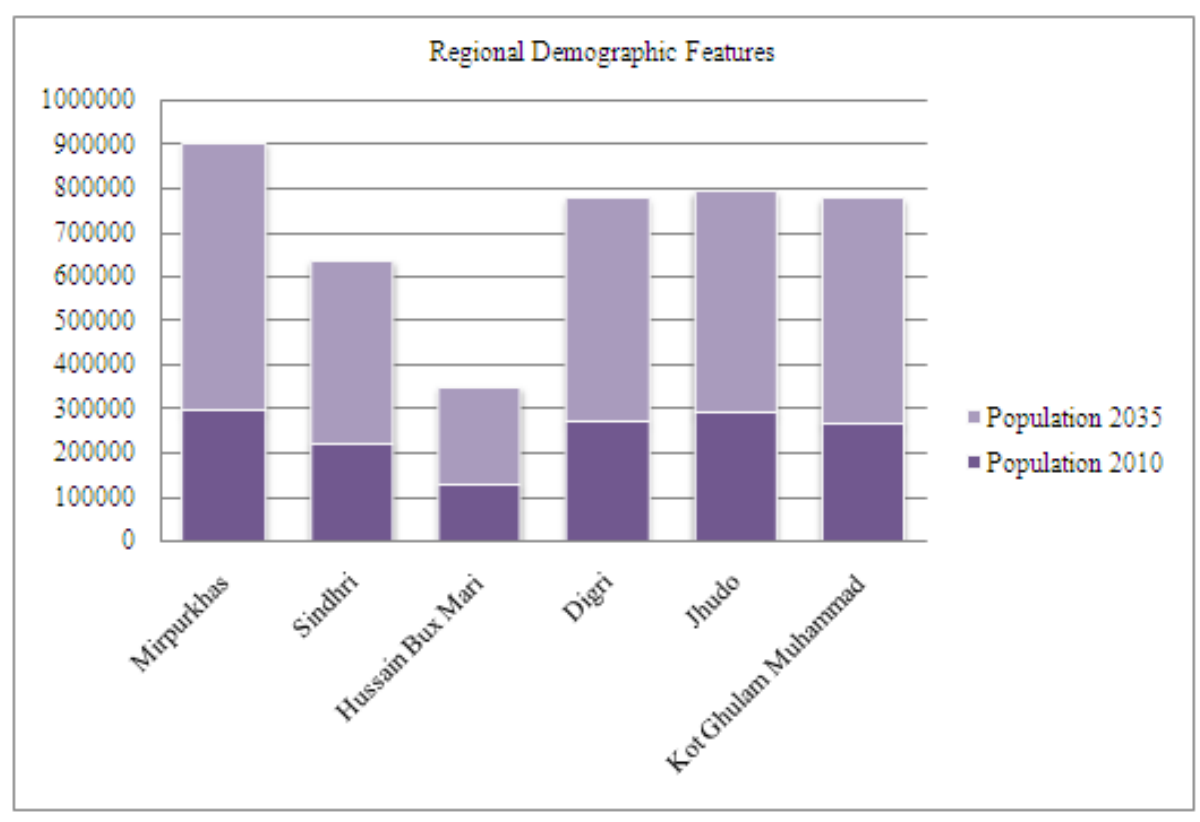

Figure 2. Regional demography from the years 2010 to 2035

Figure 2 highlights that Mirpurkhas Taluka is thickly populated as compared to other Talukas of the subregion. The reason may be an urban center of Mirpurkhas is located within the Mirpurkhas Taluka, which shows the urbanization trend as people moved from the suburbs to a city of Mirpurkhas. The correlation test (Taylor, 1990; Wang \& Hofe, 2007) was used to validate the population projection between the years 2010 and 2035, which gave satisfactory results, i.e. 0.96902 (see Appendix II).

The annual population growth rate is an imperative factor to be considered, while analyzing education sector's shortage and provision of facilities according to population trends. The average annual growth rate of the rural population during the years $1998-2010$ was about 2.49 percent as compared to a substantially higher rate of 3.18 percent during the years 1981-1998 (District Census Report, 1998). Meanwhile, the existing growth rate information was taken from the concerned authorities of the Mirpurkhas subregion, which was simply a 
projection, based on the past demographic trends in the study area. In this study, the growth rate was selected assuming the basis of past trends, government policies about birth control and family planning, which aimed to restrict the annual growth rate as low as 1.3 percent by the year 2020 (Hardey \& Leahy, 2008). By keeping in view such policy matters, past demographic trends and an existing growth rate, it was predicted that the annual growth rate would probably be restrained under three percent. The growth rate helped in projecting the population features up to the year 2035 and at the same time, it assisted in comparing the number of people with local standards, in order to determine the actual educational institution's demand.

The actual requirement of the basic education institutions of the study area was determined with the help of available local standards as described in the National Reference Manual (NRM) of Pakistan. These standards are followed by local planning agencies and development authorities in a country over the years and still are in practice. This was the only planning guide available at that time and this was the sole possible reason that NRM standards were referred in this study. The basic educational standards are given in the Table 2.

Table 2. Education standards (NRM, 1986)

\begin{tabular}{lll}
\hline Basic Institutions & For boys & For girls \\
\hline Primary School & $1 \backslash 1,800$ & $1 \backslash 2,400$ \\
Secondary School & $1 \backslash 3,900$ & $1 \backslash 17,000$ \\
High School & $1 \backslash 12,400$ & $1 \backslash 74,000$ \\
\hline
\end{tabular}

Table 2 demonstrates that boy's primary school must be provided for settlements, which have at least 1,800 population. Furthermore, a standard for the provision of Degree College was (One/Taluka). The number of available basic education institutions is provided in Table 3 (Annual Educational Report Mirpurkhas, 2010).

Table 3. Basic public sector education institutions

\begin{tabular}{llcccc}
\hline S.No & Taluka & Primary Schools & Secondary Schools & High Schools & Colleges \\
\hline 1. & Mirpurkhas & 285 & 88 & 21 & 01 \\
2. & Sindhri & 129 & 43 & 13 & 00 \\
3. & HBM & 83 & 24 & 06 & 00 \\
4. & Digri & 166 & 52 & 13 & 00 \\
5. & Jhudo & 214 & 50 & 12 & 01 \\
6. & KGM & 182 & 41 & 11 & 00 \\
\hline & TOTAL & 1,059 & 298 & 76 & 02 \\
\hline
\end{tabular}

Table 3 shows available basic education institutions in a year 2010. Among all Talukas of the subregion, Taluka Mirpurkhas has possessed the highest number of available education facilities. This was a hint to understand that policy makers always formulate the policies by keeping in view urban centers in developing countries, while the rural areas were not given proper attention. The standard for college was one per Taluka but, only two of the Taluka have this facility, while the rests of the Talukas were devoid of college service. The requirement of basic educational institutions until the year 2035 was determined, according to the available demographic standards (see Table 4). 
Table 4. Education institution's requirements

\begin{tabular}{llcccc}
\hline S.No & Taluka & Primary Schools & Secondary Schools & High Schools & Colleges \\
\hline 1. & Mirpurkhas & 338 & 154 & 47 & 00 \\
2. & Sindhri & 229 & 105 & 32 & 01 \\
3. & HBM & 125 & 57 & 17 & 01 \\
4. & Digri & 279 & 128 & 40 & 01 \\
5. & Jhudo & 277 & 127 & 40 & 00 \\
6. & KGM & 283 & 129 & 38 & 01 \\
\hline
\end{tabular}

The foundation of this calculation was based on available institutions and population features of the year 2010 . The information as provided in Table 4 was determined with the help of available standards without any gender discrimination. The education institution's demand for boys and girls can easily be retrieved with the help of Table 2. By keeping in mind the aim of the study, the focus was given to the overall calculation of education demand without any gender differences. This is why the education institution's demand was computed on total, both for boys and girls (see Table 4). This demand was also shown graphically and the education map of the study area was developed (see Figure 3).

The subregional education map was specially developed to show the demand of regional education facilities by the year 2035. The calculated number of required education institutions is much higher, which is portraying an alarming situation for the local authorities. Hence, a quick response is inevitable, if this problem has to be eradicated sooner from its roots.

Figure 3 was designed to show the graphic representation of UC wise demand throughout the study area. 


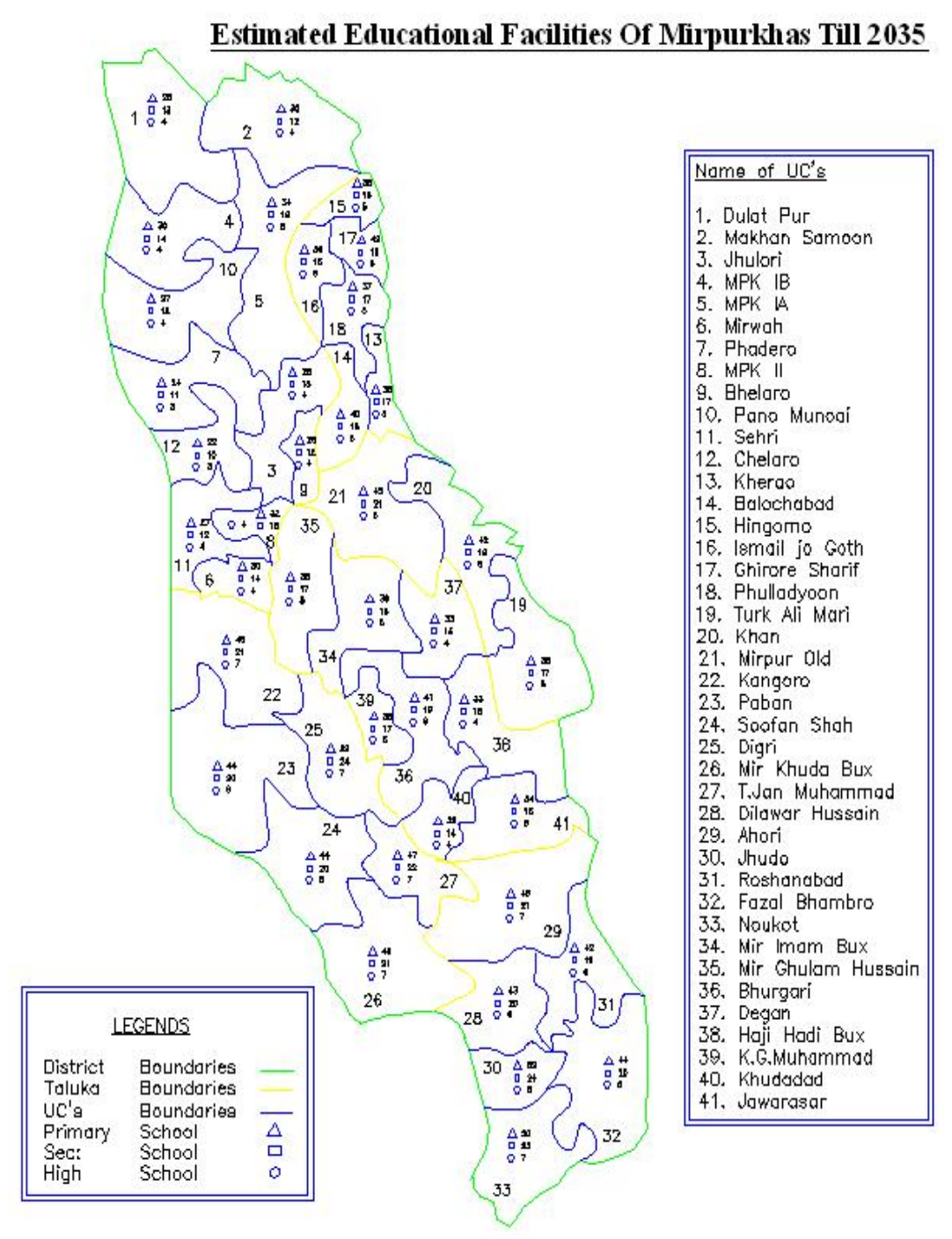

Figure 3. Projected demand of regional educational facilities

With the passage of time, more basic education facilities would be required as the population is increasing with a continuous rate. Planning policies must be implemented by keeping in view the demographic standards for the betterment of rural people (Findlay \& Borgegard, 1995) and in particular to tackle the problem of a rustic education institution's shortage. Further, the concentration should be given to educate rural people, as they could be able to understand the growing concerns of their area and could share their valued inputs.

\section{Conclusion}

The provision of basic education services should be the prime priority of the local as well as national governments. As far as Pakistan is concerned, the situation is really alarming as the literacy ratio is decreasing considerably with the increasing population. The education policy needs to be revised in order to tackle the education problems at a national level. The funds should be allocated to Provincial Governments as these can distribute the same to the concerned local agencies. Further, it is suggested that seminars and programs should be arranged, aiming the importance of education. The local rural inhabitants should be invited to attend these seminars. Efforts should be taken to confirm the public participation and their suggestions should also be given priority, to be included in policy plans.

This research study is significant in a sense that it provides an in-depth analysis of the study area with respect to the shortage of public sector education institutions and their accessibility in a deprived bucolic environment. The aim of the study was to calculate the shortage of basic education institutions of the study area, according to national standards, which was completed successfully. Different analytical techniques were also incorporated in 
order to make analysis more authentic. It is expected that education accessibility can be increased for the local rural people, if these basic educational institutions would be provided according to the standards. This study is a step further towards the prosperity of the study area and an attempt to uplift the falling standards of education in deprived rural subregions of the developing countries.

\section{Acknowledgements}

Authors are truly grateful to the Department of Civil Engineering, Universiti Teknologi PETRONAS, Malaysia for its support and the Department of City and Regional Planning, Mehran University of Engineering and Technology, Jamshoro, Sindh, Pakistan for providing assistance in data collection phase for this research article from the study area.

\section{References}

Andersson, E., Malmberg, B., \& Östh, J. (2012). Travel-to-school distances in Sweden 2000-2006: changing school geography with equality implications. Journal of Transport Geography, 23(0), 35-43. http://dx.doi.org/10.1016/j.jtrangeo.2012.03.022

Anwar, M., Green, J., \& Norris, P. (2012). Health-seeking behaviour in Pakistan: A narrative review of the existing literature. Public Health, 126(6), 507-517. http://dx.doi.org/10.1016/j.puhe.2012.02.006

Aref, A. (2011). Perceived Impact of Education on Poverty Reduction in Rural Areas of Iran. Life Science Journal 8(2), 498-501.

Asadullah, M. N. (2009). Returns to private and public education in Bangladesh and Pakistan: A comparative analysis. Journal of Asian Economics, 20(1), 77-86. http://dx.doi.org/10.1016/j.asieco.2008.05.004

Awan, M. S., Malik, N., Sarwar, H., \& Waqas, M. (2011). Impact of education on poverty reduction. Munich Personal RePEc Archive (MPRA Paper No. 31826), 1-11.

District Census Report Mirpurkhas. (1998). Population Census Organisation, Statistics Division, Govt. of Pakistan.

Education Department Mirpurkhas. (2010). Annual Educational Report Mirpurkhas. Executive District Officer (EDO) Education Department. District Government Mirpurkhas.

Farah, I., Mehmood, T., Amna, Jaffar, R., Shams, F., Iqbal, P., . . Gul-Mastoi, N. (1996). Roads to success: self sustaining primary school change in rural Pakistan. Karachi, Pakistan: World Bank as a background study for preparation of the NWFP Primary Education Project and the Pakistan Education Sector work "Improving Basic Education in Pakistan".

Fatima, A., \& Nasr, M. (2010). Financial Aid as Support for Student Accessibility to Higher Education in Pakistan. International Review of Business Research Papers, 6(3), 205-218

Filmer, D. (2000). The Structure of Social Disparities in Education: Gender and Wealth. World Bank policy research Working Paper No. 2268 World Bank policy research Working Paper No. 2268 (Vol. World Bank policy research Working Paper No. 2268). Washington, D.C.: World Bank.

Findlay, A. M., \& Borgegard, L. E. (1995). Demography, destiny and population policies. Applied Geography, 15(3), 197-202. http://dx.doi.org/10.1016/0143-6228(95)00003-M

Groot, A. D. (2007). Deprived children and education Pakistan. International Institute of Social History, University of Amsterdam.

Guagliardo, M. (2004). Spatial accessibility of primary care: Concepts, methods and challenges. International Journal of Health Geographics, 3(3).

Halai, A. (2011). Equality or equity: Gender awareness issues in secondary schools in Pakistan. International Journal of Educational Development, 31(1), 44-49. http://dx.doi.org/10.1016/j.ijedudev.2010.06.012

Hanushek, E. A. (1995). Interpreting Recent Research on Schooling in Developing Countries. University of Rochester.

Hardee, K., \& Leahy, E. (2008). Population, Fertility and Family Planning in Pakistan: A Program in Stagnation. Population Action International, 3(3).

Khan, S. U., \& Saqib, O. F. (2011). Political instability and inflation in Pakistan. Journal of Asian Economics, 22(6), 540-549. http://dx.doi.org/10.1016/j.asieco.2011.08.006

Lasker, R. D., Weiss, E. S., \& Miller, R. (2001). Partnership Synergy: A Practical Framework for Studying and 
Strengthening the Collaborative Advantage. Milbank Quarterly, 79(2), 179-205. http://dx.doi.org/10.1111/1468-0009.00203

Memon, G. R. (2007). Education in Pakistan: The Key Issues, Problems and The New Challenges. Journal of Management and Social Sciences, 3(1), 47-55.

NRM. (1986). National Reference Manual. Ministry of Housing, Works, Environmental and Urban Affairs Division. Government of Pakistan.

Pakistan, G. O. (1998). National Education Policy Draft, 1998-2010. Islamabad: Ministry of Education.

Pakistan, H. R. (2011). Humanitarian Response Pakistan. Retrieved from http://pakresponse.info/MapDataCenter.aspx

Parveen, S. (2006). Female Education at Secondary School Level in the Province of Sindh; Pakistan. Journal of Educational Research, 9(2), 16-30.

Psacharopoulos, G. (1994). Returns to investment in education: A global update. World Development, 22(9), 1325-1343. http://dx.doi.org/10.1016/0305-750X(94)90007-8

Psacharopoulos, G., \& Patrinos, H. A. (2004). Returns to investment in education: a further update. Education Economics, 12(2), 111-134. http://dx.doi.org/10.1080/0964529042000239140

Richardson, A. J., Ampt, E. S., \& Meyburg, A. H. (1995). Survey Methods for Transport Planning (1st ed.). Melbourne: Eucalyptus Press, P.O Box \# 4460, University of Melbourne, Parkville, vic. 3031.

Roberts, M. (1974). An introduction to town planning techniques. Hutchinson Educational.

Sawada, Y., \& Lokshin, M. (2009). Obstacles to school progression in rural Pakistan: An analysis of gender and sibling rivalry using field survey data. Journal of Development Economics, 88(2), 335-347. http://dx.doi.org/10.1016/j.jdeveco.2008.03.002

Schultz, T. W. (1961). Investment in Human Capital. The American Economic Review, 51(1), 1-17.

Stopher, P. R., \& Greaves, S. P. (2007). Household travel surveys: Where are we going? Transportation Research Part A: Policy and Practice, 41(5), 367-381. http://dx.doi.org/10.1016/j.tra.2006.09.005

Talpur, M. A. H., Napiah, M., Chandio, I. A., \& Khahro, S. H. (2012). Transportation Planning Survey Methodologies for the Proposed Study of Physical and Socio-economic Development of Deprived Rural Regions: A Review. Modern Applied Science, 6(7), 1-16. http://dx.doi.org/10.5539/mas.v6n7p1

Taylor, R. (1990). Interpretation of the Correlation Coefficient: A Basic Review. Journal of Diagnostic Medical Sonography, 6(1), 35-39. http://dx.doi.org/10.1177/875647939000600106

Tre'panier, M., Chapleau, R., \& Morency, C. (2008). Tools and methods for a transportation household survey. Urban \& Regional Information Systems Association (URISA), 20(2008).

Wang, X., \& Hofe, R. V. (2007). Research Methods in Urban and Regional Planning. Tsinghua University Press, Beijing and Springer-Verlag, Berlin Heidelberg.

Zaman, K., \& Khilji, B. A. (2013). The relationship between growth-inequality-poverty triangle and pro-poor growth policies in Pakistan: The twin disappointments. Economic Modelling, 30(0), 375-393. http://dx.doi.org/10.1016/j.econmod.2012.09.023

\section{Appendix I}

$$
\begin{aligned}
& P_{t}=P_{0}(1+r)^{n} \\
& r=\left(\frac{P_{t}}{P_{0}}\right) 1 / n-1
\end{aligned}
$$

Where,

$\mathrm{P}_{\mathrm{t}}=$ Projected Population

$\mathrm{P}_{0}=$ Current Population

$\mathrm{r}=$ Annual Growth Rate

$\mathrm{n}=$ Number of Years

The Equation 1 assisted in population projection, while Equation 2 used to obtain an annual regional demographic growth rate. 
A correlation test was performed by using statistical software SPSS 17.0. This test confirmed the significance level between the population of the years 2010 and 2035. The mathematical expression is given as follows:

$$
r=\frac{\frac{1}{N}-1\left(\sum x y-N \bar{x} \bar{y}\right)}{S_{x} S_{y}}
$$

Where,

$\mathrm{r}=$ Pearson's Product Moment

$\mathrm{N}=$ Sample Size

$\mathrm{x}=$ Data of variable $\mathrm{x}$, i.e., population in the year 2010

$y=$ Data of variable $y$, i.e., population in the year 2035

$\bar{x}=$ Mean of $\mathrm{x}$

$\bar{y}=$ Mean of $y$

$s_{x}=$ Standard Deviation of $\mathrm{x}$

$s_{y}=$ Standard Deviation of $\mathrm{y}$

The population for the year 2035 was projected with the help of Equations 1 and 2. For validation purposes, a correlation test was performed to validate future education institution's demand. It should be noted that planning actions and policies are always formulated for the betterment of people, who are directly correlated with the demographic characteristics of the subregion.

\section{Appendix II}

The analysis of the relationship is a generic tool, while analyzing the regional demographic characteristics. In this research article, correlation analysis was used to determine the relationship between variables, and to check the validity of Equations 1 and 2. The results can be seen as follows:

Table A1. Correlation analysis

\begin{tabular}{llll}
\hline Statistical Test & & Population 2010 & Population 2035 \\
\hline \multirow{2}{*}{ Population 2010 } & Pearson Correlation & 1.000 & 0.969 \\
& Sig. (2-tailed) & & 0.001 \\
& N & 6 & 6 \\
\hline \multirow{2}{*}{ Population 2035 } & Pearson Correlation & 0.969 & 1 \\
& Sig. (2-tailed) & 0.001 & \\
& N & 6 & 6 \\
\hline
\end{tabular}

The value of " $\mathrm{r}$ " was calculated as 0.96902 . This shows the positive and strong correlation between the variables "x" and " $y$ ", i.e. the population by the year 2010 and 2035. In other words, (null hypothesis- $\mathrm{H}_{0}$ ) is rejected, and it is ascertained that variable " $\mathrm{x}$ " and " $\mathrm{y}$ " are highly correlated. The coefficient of determination was calculated to know the variance in variable " $y$ " predicted by a variable " $x$ ", which is given as, $r^{2}=(0.96902)^{2}$ or $(93 \%)$; hence it is concluded that (93\%) of the variance in " $y$ " can be accounted for " $x$ ". Therefore, it is proved that population, and the education institution's demands were projected accurately up to the year 2035 for the study area.

\section{Copyrights}

Copyright for this article is retained by the author(s), with first publication rights granted to the journal.

This is an open-access article distributed under the terms and conditions of the Creative Commons Attribution license (http://creativecommons.org/licenses/by/3.0/). 